\title{
MALE GENITALIA OF SOME NEPALESE SPECIES OF Onthophagus LATREILLE AND ITS TAXONOMIC IMPORTANCE Shyam Prasad Mahto*
}

\author{
ABSTRACT \\ The male genitalia of nine species of Onthophagus Latreille are \\ described here.
}

\section{INTRODUCTION}

Genus Onthophagus Latreille is a predominent genus of the subfamily Coprinae, vastly outnumbering other genera of dung beetles in most parts of the world. These beetles are small, smooth and have compact body. These are easily recognised by absence of scutellum, elytra with one lateral carina, pronotum without a strong basal groove, and four posterior tarsi not broadly dilated.

In recent taxonomic studies of insects, the male genitalia has been considered as a good taxonomic character due to its constant nature of structure. However, the genitalia has been completely ignored by Arrow (1931) in his Fauna volume on Coprinae beetles.

\section{MATERIALS AND METHODS}

Specimens of Onthophagus (pactolus (Fabricius), O. aenescens (Wiedemann), O. ramosellus Bates, O. sternalis Arrow, O. catta (Fabricius), $O$. bonasus (Fabricius), O. rectecornutus Lansberge, $O$. atropolitus Orbigny, $O$. sagittarius Fabricius) were collected by the author from different forests, grass lands, rural and urban localities of Dhanusha district, Nepal from dung of the herbivorous animals primarily of cows and buffaloes.

Both preserved and freshly killed specimens were used to study the male genitalia. The dry preserved specimens were, however, relaxed in boiling water and their abdomens were treated with $10 \% \mathrm{KOH}$ solution for few days to dissolve the soft tissues in and around the membranous and sclerotised structure of genitalia. Abdomens were dissected under stereo-binocular microscope to expose the genitalia which were then taken out with the help of forceps and mounted in Canada balsam after dehydration process only (Singh et al., 1983; Sewak, 1984, 1985, 1986 and 1988).

Photographs of male genitalia were taken by German microphotographic binocular microscope and were developed in the digital colour laboratory.

\section{OBSERVATIONS}

In this study, the following parts of the male genitalia of Onthophagus species were considered. The male genitalia of dung beetles consist of various sclerotized and membranous parts arranged around the terminal portion of the ejaculatory duct the considered parts are as follows:

(a) Phallobase (Pb). It is proximal, long, hollow, highly sclerotized structure, forming complete ring above the parameres and aedeagus, and opens apically by wide orifice into which the ejaculatory ducts enter. At rest the phallobase contains aedeagus and parameres.

Dr. Mahato is an Associate Professor at Department of Zoology R.R.M. Campus, T.U., Janakpur, Nepal. 
(b) Paramere (Pm). It is a paired structure and is derived from the phallic lobes. These are in continuation with the phallobase and are highly sclerotized, lateral appendages, which act like claspers during copulation.

(c) Aedeagus (Aed). It is also known as phallus (Snodgrass, 1935) and is a strong, symmetrical, sclerotized median tube and functions as the main copulatory organ. It has an aedeagal apodeme on dorsal side for the attachment of muscles which act like lever for the movement of endophallus.

(d) Endophallus (End). It is a muscular internal structure situated inside the phallobase; it becomes everted into the female gonopore during coitus. Thus, it is the functional intromittent organ.

The ring shaped phallobase and tubular aedeagus of male genitalia of all the recorded species in the present study showed a closer resemblance with each other while the structures of parameres and endophallus are greatly different at species level.

\section{RESULTS}

Study made on the male genetulia of Onthophagus species revealed the following features:

Onthophagus pactolus (Fig. 1): Parameres are rectangular in shape. Endophallus is broad and rectangular.

Onthophagus aenescens (Fig. 2): Parameres are apically pointed, spine-like and curved inward forming a forcep-like structure. Endophallus is broadened apically and narrow proximally.

Onthophagus remosellus (Fig. 3): Parameres are broad apically and pointed proximally. Inner margin is furnished with sensory bristles. Endophallus is trilobed.

Onthophagus sternalis (Fig. 4): Parameres are broad and rounded apically. Endophallus is rectangular in shape.

Onthophagus catta (Fig. 5): Parameres are broad and round apically and are furnished with sensory bristles on inner margin. The dorsal surface of parameres has a conical sclerotized strcuture at the middle. Endophallus is an elongated and bilobed structure; the right lobe is broad and segmented apically and narrow proximally while left lobe is tubular.

Onthophagus bonasus (Fig. 6): Parameres are broad and rounded apically and are furnished with sensory bristles on inner margin. The dorsal surface of parameres has two segmented glandular sclerotized structure at the middle. Endophallus is bilobed; right lobe is broad and rounded apically while it is narrow proximally, the left lobe is tubular.

Onthophagus rectecornutus (Fig. 7): Parameres are rectangular in shape and the lower margin is furnished with sensory bristles. The dorsal surface of the paramere has a clavate sclerotized structure at the middle. Endophallus is bilobed apically and narow proximally.

Onthophagus atropolitus (Fig. 8): Parameres are broad and rounded apically. Endophallus is hammer - shaped.

Onthophagus sagittarius (Fig. 9): Parameres are conical shaped. Endophallus is flattened and rectangular in shape with two finger-like processes at the proximal end. 

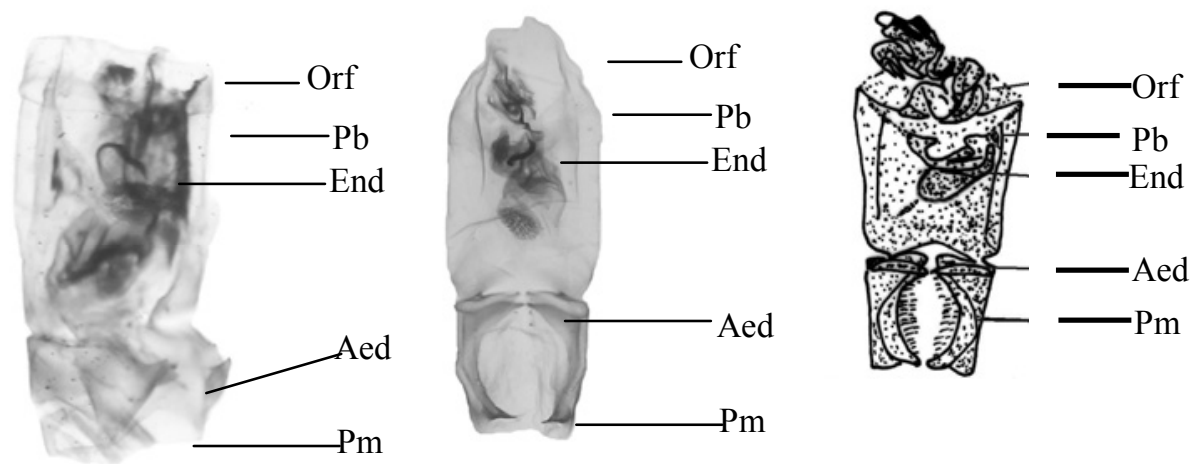

Fig. 1: Male Genitalia of Onthophagus pactolus F. (Length $1.5 \mathrm{~mm}$ )

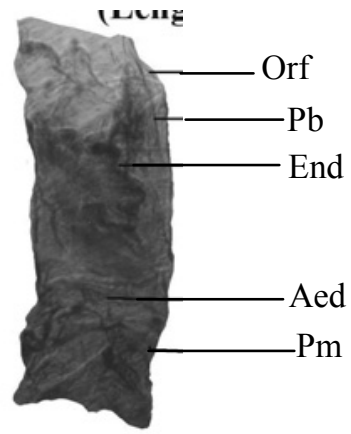

Fig. 2: Male genitalia of Onthophagus aenescens Wied (Length $1.5 \mathrm{~mm}$ )
Fig. 3: Male genitalia of Onthophagus ramosellus Bates (Length - 1mm)
Fig. 4 Male genitalia of Onthophagus sternalis Arrow

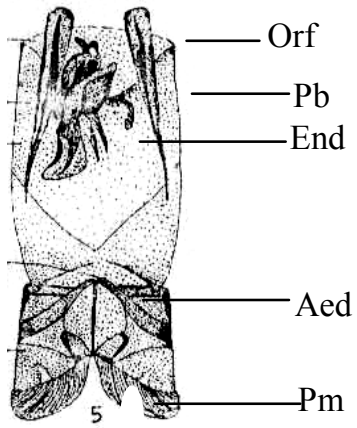

Fig. 7: Male genitalia of Onthophagus rectecornutus Lansb. Length $1.5 \mathrm{~mm}$ (Source: Sewak, 1986)

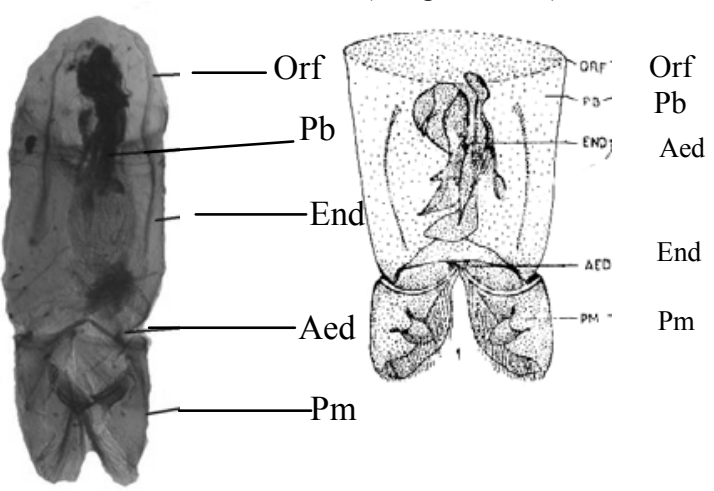

Fig. 5: Male genitalia of Onthophagus catta F. (Length-2mm)

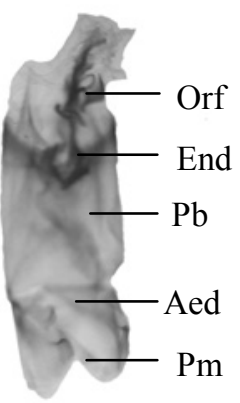

Fig. 3: Male genitalia of Onthophagus atropolitus d' Orb. (Length $3 \mathrm{~mm}$ )
Fig. 6: Male genitalia of Onthophagus bonasus F.

Length $1.5 \mathrm{~mm}$

(Source: Sewak, 1986)

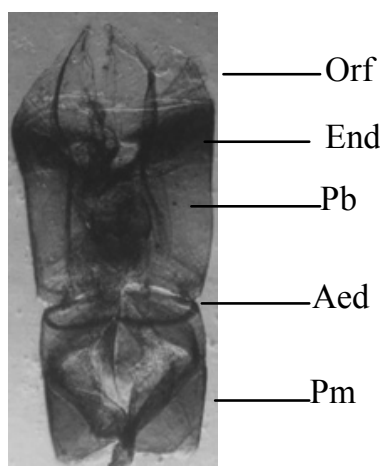

Fig. 3: Male genitalia of Onthophagus sagittarius F. (Length $1 \mathrm{~mm}$ ) 


\section{ABBREVIATIONS}

Aed: Aedeagus, End: Endophallus, Orf: Orifice, Pb: Phallobase, Pm:Parameres

\section{TAXONOMIC IMPORTANCE}

The ring shaped phallobase and tubular aedeagus of male genitalia of all the recorded genera of Coprinae in the present study showed a closer resemblance with each other while the structures of parameres and endophallus are greatly different at both generic and species level. Parameres are elongated and bristilized in Heliocopris, elongated and bristleless in Catharsius, pointed and bristleless in Onitis, pointed and bristilized in Copris, smaller and bristilized or bristleless in Onthophagus and very small and bristleless in Oniticellus. The endophallus was observed broadened apically and narrow proximally in Heliocopris and Catharsius, bristilized sole shaped in Copris, $\mathrm{H}$ or Y-shaped in Onitis, broadened apically in Oniticellus and varying shaped in Onthophagus and Gymnopleurus. Thus, the evidence of male genitalia of dung beetles confirms the independent status in Scarabaeidae.

\section{ACKNOWLEDGEMENT}

Author is grateful to Prof. Dr. V.K. Thapa (Retd.) former Head, Central Department of Zoology, T.U., Kirtipur for his precious suggestions and for providing laboratory facilities.

\section{WORKS CITED}

Arrow, G. J. (1931). The Fauna of British India including Ceylon and Burma. Coleoptera, Lamellicornia, III. Taylor and Francis, London, pp. 1-428.

Sewak, R. 1984. Male genitalia of some Indian species of Copris Geoffroy (Coleoptera: Scarabaeidae) and its taxonomic importance. Oikoassay, 1(1-2): 20-23.

--- (1985a). Male genitalia of some Indian species of Onitis Fabricius (Coleoptera: Scarabaeidae). Oikoassay, 2(1): 18-19.

--- (1985b). Male genitalia of some species of Catharsius Hope (Coleoptera: Scarabaeidae) and its taxonomic importance. J. Anim. Morphol. Physiol, 33(1-2): 269-271.

--- (1985c). On a collection of dung beetles (Coleoptera: Scarabaeidae: Coprinae) from Gujarat, India. Oikoassay, 2(2): 33-35.

--- 1986a). Male genitalia of Indian Onthophagus Latr. (Coleoptera: Scarabaeidae) and its taxonomic importance. J. Anim. Morphol. Physiol, 33(1-2): 135-140.

--- (1986b). On a collection of dung beetles (Coleoptera: Scarabaeidae: Coprinae) from Rajasthan, India. Oikoassay, 3(1): 11-16.

--- (1988a). Male genitalia of Indian Gymnopleurus Illiger (Coleoptera: Scarabaeidae) and its taxonomic importance. Oikoassay, 5(2): 43-45.

--- (1988b). Male genitalia of Indian Oniticellus Serville (Coleoptera: Scarabaeidae) and its taxonomic importance. J. Anim. Morphol. Physiol, 35(2): 165-168.

Singh, S., et al. (1983). Male genitalia of some indian species of Heliocopris Burm. (Coleoptera: Scarabaeidae). J. Agric. Sci. Res. 25: 67-72.

Snodgrass, R.E. (1935). Principles of Insect Morphology. MC Grow Hill Book Co. New York Cit. IX +677, pp. 319 figs. 